\title{
Literature Review on the Effect of Balanced Scorecard on Employee Wellbeing
}

\author{
Ceren Peri Cignitas ${ }^{1}$, Juan Antonio Torrents Arevalo ${ }^{2} \&$ Jordi Vilajosana Crusells ${ }^{2}$ \\ ${ }^{1}$ Doctoral Student, Business Administration, and Management, Polytechnic University of Catalonia-Barcelona \\ Tech., Barcelona, Spain \\ ${ }^{2}$ Professor in the Department of Management at the Polytechnic University of Catalonia, Barcelona Tech., \\ Barcelona, Spain \\ Correspondence: Ceren Peri Cignitas, Doctoral Student, Business Administration, and Management, Polytechnic \\ University of Catalonia-Barcelona Tech., Barcelona, Spain. E-mail: cperi.cignitas@gmail.com
}

Received: December 10, 2021

Accepted: January 14, 2022

Online Published: February 23, 2022

doi:10.5539/ijbm.v17n3p103

URL: https://doi.org/10.5539/ijbm.v17n3p103

\begin{abstract}
Employee well-being is an important key area of human resource development (HRD), such as performance measurement, employee productivity, employee development, and motivation. Employees are a key element in realizing the organization's strategies. For this reason, measuring employee performance is important in terms of ensuring the efficiency and sustainability of the system and is an HR Strategy. The aim is to determine whether there is a quasi-experimentally demonstrable relationship between. Balanced Scorecard (BSC), and employee well-being. The study conducted qualitative and quantitative research based solely on the bibliographical review of previous theoretical/conceptual and empirical articles on the subject. Quantitative measurement data were collected from 9 empirical studies, and a total of 121 qualitative studies were reviewed. The findings of the study proved that there is a strong relationship between employee happiness and the increase in performance of organizations, while the BSC application increases employee happiness and indirectly the happiness of the organization. This article is an important reference work for HR development with Balanced Scorecard strategies.
\end{abstract}

Keywords: balanced scorecard, happiness, positive psychology, employee well-being

\section{Introduction}

Employee happiness is one of the most important issues in HR development. Being happy at work is more than just making some investments and getting something in return (Boehm, 2008). Individual factors such as personal characteristics, level of perception, psychological factors that can cause stress, and emotional intelligence all affect well-being in the work environment. (Christakis \& Fowler, 2008). Components of Organizational Happiness has been stated by Fisher in three field job satisfaction, organizational commitment, and work engagement (Fisher, 2010).

Employee performance has been defined by researchers as higher productivity, higher profitability, and higher positivity at the workplace community, in association with employees' positive feelings and positive workplace perceptions. Employee engagement or retention has been defined by researchers as greater work calling, organizational commitment, and low employee turnover, in association with employees' positive perception over the meaning and personal development they gain through work. Numerous empirical studies on work engagement, flow, and mindfulness maintain the positive outcomes generated from these positive states. According to (Buyukbay, 2017). Employee's attribute three different meanings to their work: duty, career, and passion. (Diener, Suh, \& Oishi, 1997).

Organizations are focused on job satisfaction, organizational commitment, and the ability to increase productivity in the organization. Hence employee feelings and attitudes are important for satisfaction level. Positive organizational behaviour is defined as studies on the strengths and psychological capacities of HR that can be effectively managed, measured, and developed in a positive way to improve performance in organizations. (Seligman, 2000). Positive organizational behaviour, the focus of which is employee strengths and psychological abilities, is how to develop and develop employees' strengths. (Deming, 2000). (Stankiewicz, 2014). To create the system of Positive Organizational Potential in an organization, eight following key areas (subsystems) must be developed first (Schulz, 2005): (1) Corporate governance, (2) Leadership, (3) Trust, (4) Interpersonal relationships, 
(5) Talent management, (6) The language of internal communication, (7) Organizational citizenship behaviours, (8) Corporate social responsibility.

\subsection{Balanced Scorecard (BSC)}

Balanced Scorecard which is used for organizational performance evaluation is one of the multi-dimensional performance evaluation methods. The BSC measures an organization's performance from four five perspectives, which are: financial, customer, internal business process, learning and growth, and environmental perspectives (Figge \& Hahn, 2002). (Kassahun, 2010), (Kaplan R. \&., 1996)

Financial Perspective: Financial perspective shows the long-term objectives of organizations to provide value for the improvement of profitability and other financial objectives.

Customer Perspective: This perspective considers the capacity of a business to secure qualitative goods and services for its clients, the effectiveness of offering those services, and addresses the concerns of customers to develop ongoing support. (Simbolon S. M., 2018).

Internal Business Perspective: This is archived by identifying the customers' needs, and in this way while developing new products and services through innovation to meet customer demands (Kaplan R. \&., 1996).

Learning and Growth Perspective: Kaplan and Norton (Kaplan R. \&., 2000) identified three sources of a business for learning and growth: people, informational system, and organizational processes (Kaplan R. \&., 1996). Organizations while recognizing there is a large gap between the abilities of employees and the system process of financials, customers, and products, organizations have begun to invest in training employees, increasing employee satisfaction, improving information and technology systems through the BSC learning and growth perspective. (Jelenic, 2011) The learning and growth perspective, which is one of the balanced scorecard perspectives, is of great importance for the satisfaction and well-being of the employee, who is the key factor in organizational success. This perspective helps increase value for the company by improving business processes and people. The learning and growth perspective essentially means the quality of human resources in the organization.

Literature on implementing and using the BSC: Ahn, 2001; Butler et al., 1997; Malmi, 2001; Papalexandris et al., 2004; Speckbacher et al., 2003, Davis \& Albright, 2004, 2003; Hoque \& James, 2000, Epstein \& Manzoni, 1998; Kasurinen, 2002; Norreklit, 2000, 2003. Chih-Chao Chung, Li-Chung Chao, Chih-Hong Chen and, on Shi-Jer Lou, Malina and Selto 2001, Madsen and Steinheim 2015, Thananchayana, 2018, Sirait, B 2018, Elbannab S 2020, Suzer 2020; their findings point to a significantly positive relationship between the usage of typical BSC measures and superior performance.

Literature on relationship between BSC and employee well-being: The job content (interest, prestige, and independence), pay, and interpersonal relationships were the most motivators at the workplace. The employee's feelings about the jobs to a large extent were the relationships you have with other people at work, the actual job itself, the degree to which you feel 'motivated' by your job. the style of supervision that your superiors use, the extent to which you may identify with the public image or goals of your organization, current career opportunities, the feeling have about the way you and your efforts are valued, the kind of work or tasks that you are required to perform and the degree to which you feel that you can personally develop or grow in the job. (OPIYO, 2010).

Impact of BSC on organization performance: Organizations develop their employees' skills and performance which led to increased efficiency in their internal business processes. This led to improved customer satisfaction and increased market share, which in turn led to an increase in the firm's profitability. It was affirmed that increased profitability boosted the other functions of the firms which improved rewards to employees and more participation in corporate social responsibilities. It also gave the firms a positive public image and increased competitiveness. (Kairu, 2013). Study results indicate that implementing the BSC improves employee commitment, the organizational climate, job satisfaction, and job dedication. A clear relationship with the satisfaction of employees within the organization; shows that the BSC implementation is significantly related to positive employees' affective reactions (Molina, 2014).

To derive full benefits from the scorecard approach companies must work harder to get employees at all levels on board with the method. The study investigated the role of a balanced scorecard in enhancing the job satisfaction of employees. The results revealed that there is a positive correlation between a balanced scorecard and job satisfaction (Narayanamma, 2017).

The better the leadership involvement through BSC implementation, the more employees' organizational commitment will increase the employees' roles are positively correlated with organizational commitment. (Simbolon, 2018). In general, what the whole thing shows is that the implementation of BSC at least has helped the organization in establishing a planning and measurement system that drew a tangible experience among the 
general employees. The BSC has somehow helped them to give due attention to the customers they are serving. (LEMMA, 2018).

This article aims to present the findings of a systematic review of the empirical literature on the impact of Balanced Scorecard on employee well-being to establish the contours of outcomes of performance measurement system. Given the growth in empirical research on employee well-being that has taken place in recent years, especially since researchers concluded that relatively few studies had been undertaken, this paper is warranted for the HRD community. This paper aims to address the question, "What is the empirical evidence base concerning Balanced Scorecard and Employee Well-being. Important aims of the study are to inform and help theory and practice in HRD.

Research questions are broken down into 4 sub-questions as follows:

Research Question 1: What is the relationship between job satisfaction, work engagement, commitment, and employee well-being with the workplace: H1-The reviewed empirical studies have found out there is a positive correlation between job satisfaction, work engagement, commitment, and employee well-being.

Research Question 2-What is the relationship between Employee well-being and Organizational Performance? H2-The reviewed empirical studies have found out there is a positive correlation between Employee well-being and Organizational Performance.

Research Question 3-What is the relationship between the Increasing in Organizational performance and a Balanced Scorecard? H3-The reviewed empirical studies have found out there is a positive correlation between the increase in organizational performance and a Balanced Scorecard.

Research Question 4-What is the relationship between the Employee well-being and Balanced Scorecard? H4-The reviewed empirical studies have found out there is a positive impact of BSC on employee well-being.

The study outlines the methods used to search for and extract data from relevant articles and the decisions made about inclusion criteria and address each of the research questions.

\section{Method}

A study carried out qualitative research based on an exclusively bibliographic review of theoretical/conceptual and empirical papers, previously carried out on the subject. According to (Lueg, 2015), the methodology of the systematic review of the literature allows a review of the evidence on a formulated question, using systematic and explicit methods to identify, select and evaluate critically relevant primary research and extract and analyze data from the studies included in the review. Bibliographic research was carried out from 2000 until the end of 2020, especially in the online library and online journal website that allows unlimited and permanent access to research and higher education institutions, to full texts from several scientific newspapers and e-books of some of the most important content providers. The primary objective of the present research is to explore the relationship between BSC, workplace happiness, and employee well-being. Three dimensions of employee well-being, that is, job satisfaction, employee commitment, and positive management, are explored herewith.

Qualitative research involves the process of constructing the framework and finalizing the elements to contribute to employee happiness. As the first step, this research process collected and analyzed various elements assumed to explain as contributors to employee well-being. It has been being collected based on a series of detailed research in literature, the best business practices for creating happiness at work, and the perception of professionals on employee well-being. Reviewed the literature on HRM systems and practices, organizational performance, happiness, well-being, positive psychology, positive leadership, and relationships.

Quantitative research involves the measures used, the setting, and the sample for testing the research model. And then will introduce the process utilized for data analysis. It has determined the perception of empirical studies on employee well-being, positive leadership, BSC practice through previous studies predicting the determining criteria of well-being concerning their work performance in the work context.

It has been conducted from secondary data which has been surveyed employee happiness, positive management, and positive workplace. These studies have been selected based on the conclusions which investigated employee well-being, positive management, positive leadership, and BSC.

The use of secondary data, or existing data that are freely available to researchers who were not involved in the original study, has a long and rich tradition in the social sciences. Secondary data analysis refers to the analysis of existing data collected by others. The secondary analysis allows researchers to investigate research questions using large-scale data sets that are often inclusive of under-represented groups while saving time and resources. The secondary data has been used in this study. For data analysis, the following steps have been applied. Briner and 
Denyer (2010).

1- Research questions have been determined.

2- The source of data and location have been determined.

3- Relevance of the data has been evaluated such as the original purpose of data, collecting time, population, sampling strategy, and sample and statistical methods for the conclusion

4-Credibility of the data has been assessed with establishing the credentials of the original researchers, searching for a full explication of methods including any problems encountered, determining how consistent the data is with data from other sources, and discovering whether the data has been used in any credible published research.

5-Analysis; results of empirical findings have been reviewed and relevant parts have been gathered.

The study has confined search to studies published in English between 2000 and 2020 which contained empirical data. HRD field is one with interdisciplinary foundations, sought to include empirical studies from human resource management, management, organizational behavior, sociology, and ethics.

In light of the interchangeable way in which the terms "meaning of happiness" "positive organization psychology", "organizational well-being' well-being" and "employee well-being" have been used (Fisher 2020: Seligman et al 2000), studies that used the term "happiness" rather than "well-being" were scrutinized individually to ascertain whether their primary focus was on the "employee well-being" in which case they were excluded, or on "life satisfaction". It is important to note that the concepts of "happiness", "life satisfaction" and "well-being" are semisynonymous in terms of the components of happiness. Veenhoven (1996) defined happiness as life satisfaction. (Seligman, 2002, Ryan \& Deci, 2001; Diener, 2000; Waterman, 1993, Ryff, 1989); where later, with the eudaimonia essence, it has gained more attribution with the term 'well-being' (Seligman, 2011; Ryan \& Deci, 2001; Ryff \& Keyes, 1995; Andrew \& Withey, 1976). Numerous researchers have been studying happiness or well-being, under the field of positive psychology (Buyukbay, 2017).

The results of the structured search were filtered by including only peer-reviewed items to ensure quality and reliability and by using the "de-duplication" function in the RefWorks (4) bibliographic management software, which brought the number of search results for evaluation. The study reviewed the same number of randomly selected articles. It excluded a total of 421 articles that did not meet the pre-selection inclusion criteria. This left a total of 129 items for data extraction these were then downloaded in full of their respective databases. Then, data were extracted using a form for each research question. The final phase of the review includes analysis and synthesis before distribution. The study pioneered the analysis of the extracted data according to the research questions and developed detailed summary tables that provide a comprehensive overview of the study findings related to each research question. The study used this analysis to explore connections between topics and subtopics, weigh the quality and quantity of evidence, and develop an understanding of the evolution of the field over time.

\section{Result}

\subsection{Overview}

Of the included studies, 32 were Balanced Scorecard development and implementation, 55 were happiness and employee well-being, 30 were leadership and positive organizational behaviour (positive management), and 9 were the impact of BSC on employee well-being. In 9 empirical studies, various statistical methods such as Exploratory Factor Analysis (ECA), Statistical Package for Social Sciences (SPSS), Meta-Analysis (MA), WERS, Structural Equation Modelling (SEM), Panel Data Regression modelling (PDRM), and Growth Curve Analysis (GCA) was used for data analysis. Samples were usually selected from employees and senior managers to determine the correlation/relationship between dimensions through questionnaires.

\subsubsection{Definitions and Measures of Employee Well-Being in Workplace}

There was a consensus over the definition of employee well-being and workplace happiness across all the papers that were reviewed. Employee well-being has been defined as the overall quality of an employee's experience and functioning at work. (Ryff, 1995) Employee well-being is often defined in terms of three dimensions Psychological Well-Being, Social Well-Being, Physical Well-Being (Diener, 2004). Psychologists tend to focus on two components of psychological well-being: hedonic and eudaimonic (Ryan \& Deci, 2001). The hedonic component is about subjective experiences of pleasure, which is the balance of positive and negative thoughts and feelings in individuals' judgments. In organizations, research on job satisfaction represents the hedonic approach to understanding psychological well-being: job satisfaction is defined in terms of employees' subjective judgments about their work situations (Weiss, 2002). Physical well-being refers to both objective physiological measures and subjective experiences of bodily health. Psychological well-being and physical well-being are properties of the 
individual employee, social well-being focuses on the interactions that occur between employees (Bradbury, 2000). Based on 58 different studies, employee well-being has been divided into three different fields that are still related to each other which were job satisfaction, organizational commitment, and work engagement. According to Fisher, there are three levels of happiness in the workplace. The first is seen as temporary happiness at work (short-term emotional state), the second is happiness at the individual level (job satisfaction, commitment, and emotional state) and the third is happiness at the unit level (Fisher, 2010).

Job Satisfaction: Herzberg's (1959) job satisfaction theory is the most known. This theory consists of two parts, hygiene (internal) and motivational (external). Hygiene factors which are a success, self-determination, job description, responsibility is improving job satisfaction. On the other hand, motivational factors provide job satisfaction with business policies, salaries, management, supervision, business lines, interpersonal communication, status, job security, and communication with top management, and their lack leads to dissatisfaction. When employees feel fairly treated by the organization then they feel safe with higher job satisfaction.

Organizational Commitment: as defined by Porter (1974) has three major components: (1) a strong belief in and acceptance of the organization's goals, (2) a willingness to exert considerable effort on behalf of the organization, and (3) a definite desire to maintain organizational membership. Organizational commitment is the feeling of belonging to the organization where the employee is a member. According to Fisher (Fisher, 2010), organizational commitment is the communication of employees in the same line with the purpose and values of the organization. Organizational commitment consists of 3 parts: emotional commitment, continuation commitment, and normative commitment

Work Engagement (Thriving, Igor, Flow, Mood, and Motivation, etc): Any effort to maximize organizational effectiveness requires a higher level of business engagement among members of an organization. Therefore, job engagement is an important motivational variable for the organization. If the employee feels good to do his/her job well, the engagement increases, otherwise it falls. Engagement is a positive effect associated with the job and the work setting connoting or explicitly indicating feelings of persistence, vitality, energy, dedication, absorption, enthusiasm, alertness, and pride.

According to Seligman and Csikszentmihalyi (Seligman, 2000), positive organizational psychology is the third component of positive psychology, posited by 2000 , positive organizations are the organizational level that leads individuals to better citizenship such as responsibility, altruism, democracy, tolerance and works ethics and virtues. Factors such as the job itself, working conditions, relationships, and managers affect these levels of well-being. Positive organizational behaviour is defined as studies on the strengths and psychological capacities of human resources that can be effectively managed, measured, and developed in a positive way to improve performance in organizations. (Diener, 1997).

Stankiewicz' (2014) studies enable us to formulate the assumption that to create the system of Positive Organizational Potential in a company, nine following key areas (subsystems) must be developed first: (1) Corporate governance, 2 (Leadership), (3) Middle managers, (4) Trust, (5) Interpersonal relationships, (6) Talent management, (7) The language of internal communication, (8) Organisational citizenship behaviours, (9) Corporate social responsibility.

Table 1. Correlation between job satisfaction, work engagement, and organizational commitment (Buyukbay, 2017)

\begin{tabular}{lllllll}
\hline Variances & Mean & Std. Dev & EP & JS & WE & OC \\
\hline Employee Performance (EP) & 3.4028 & 0.79479 & 1 & & & \\
Job Satisfaction- JS & 4.0803 & 0.70300 & 0.240 & 1 & & \\
Work Engagement -WE & 3.6084 & 0.95779 & 0.183 & 0.621 & 1 & \\
Organizational Commitment -OC & 4.2479 & 0.62746 & 0.189 & 0.467 & 0.365 & 1 \\
\hline
\end{tabular}

Notes. ** Correlation is significant at $(\mathrm{P}<0,01) *(\mathrm{P}<0,05) 1$ : Pearson correlation.

Table 1 shows that there are significant relationships between employee performance, job satisfaction, job commitment, and organizational commitment, this finding is supported by the literature (Leroy et al., 2013; Reid, 2011). 
Table 2. Correlation between HRM performance system, productivity and employee well -being (Hoang Ho, 2019)

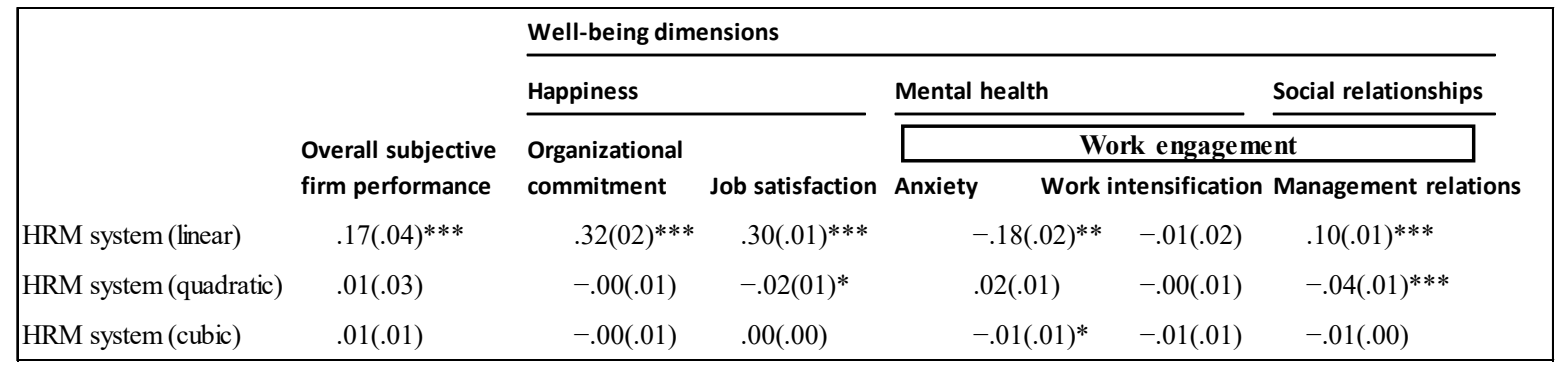

Notes. HRM, human resource management. ${ }^{*} \mathrm{p}<.05 ;{ }^{* *} \mathrm{p}<.01 ; * * * \mathrm{p}<.001$.

Table 2 shows that there are relationships between employee well-being and Productivity.

Table 3. Regression model summarizes for the effect of balanced scorecard on job satisfaction (Narayanamma, 2017)

\begin{tabular}{lllllllll}
\hline \multirow{2}{*}{ Model } & \multirow{2}{*}{$\mathrm{R}$} & R Square & $\begin{array}{l}\text { Adjusted } \\
\text { Square }\end{array}$ & $\begin{array}{l}\text { Error of the } \\
\text { Estimate }\end{array}$ & ANNOVA & & & \\
Df1 & Df2 & F-Value & Sig. \\
\hline 1 & $.344 \mathrm{a}$ & 0.119 & 0.117 & 0.32443 & 1 & 557 & 74.893 & $.000 \mathrm{a}$ \\
\hline
\end{tabular}

According to table 3; there is a positive correlation between a balanced scorecard and job satisfaction. The better is the implementation of a balanced scorecard the high will be the job satisfaction.

\subsection{Definition of Balanced Scorecard}

Balanced Scorecard systems were first founded in 1987 by Schneiderman at Analog Devices which was a mediumsized company. in 1990, the Balanced Scorecard was developed by Robert Kaplan, an accounting professor at Harvard University, and David Norton, a consultant also from the Boston area (Epstein \& Manzoni, 1997). The BSC measures an organization's performance from four five perspectives, which are: financial, customer, internal business process, learning and growth, and environmental perspectives (Figge \& Hahn, 2002). Financial Perspective shows long-term objectives of an organ to provide value for improving the profitability and other financial objectives (Kaplan \& Norton, 1996). Customer perspective considers the capacity of a business to secure qualitative goods and services for its clients, effectiveness of offering those services and addresses the concerns of customers to develop ongoing support. Internal Business Perspective: This is archived by identifying the customers' needs, and in this way while developing new products and services through innovation to meet customer demands (Kaplan, 1996).

\subsection{Theory of Learning and Growth Perspective to Increase Employee Well-Being}

The Role of Balanced Scorecard Learning and Growth Perspective in Organizational Happiness and Employee' Well-being: The balanced scorecard (BSC) is a broader concept of performance measuring, which highlights the non-financial performance to encourage proactive management style. (Kaplan \& Norton, 1996). The organizations are forced to innovate and develop new techniques for improving the quality and functionality of products, reducing costs, and, of course, the answer to the increasingly sophisticated customers' demands to survive in the market. The leaders, which care about their high business performance, have realized that the market value of their property increases with greater participation of "intangibles" (intellectual) resources about the tangible property. In the balanced scorecard, there is a transformation of intangible assets and intellectual capital in terms of giving a more realistic view of a company's values. The learning and growth perspective supports innovation and encourages the free flow of ideas through the company. It helps increase revenues (the products and services are delivered to market faster) and reduce costs (Eliminates redundant and unnecessary business processes). This process increases the time that employees spend in the company because their knowledge and efforts are valued by the system of rewards. Learning and growth in an organization increase the value of the company and its competitiveness, it increases the efficiency and effectiveness, the relationship of all resources, and innovation. (Jelenic, 2011) 
The organizations while recognizing there is a large gap between the abilities of employees and the system process of financials, customers, and products, have begun to invest in training employees, increasing employee satisfaction, improving information and technology systems through the BSC learning and growth perspective.

Kaplan and Norton emphasize that "learning" is more than "training" as it involves facilitated communication between employees at all levels and sharing organizational knowledge. To keep up with the times and to anticipate certain situations and events frequently, it is essential for employees to constantly improve themselves, learn and develop a corporate culture and attitude related to individual and corporate progress. In any case, learning and development is a fundamental foundation for the success of any organization facing continuous improvement. Qualified employees, ideas, culture, and knowledge concepts have become the main elements that are important for the development, functioning, and improvement of the performance of organizations. Satisfied employees can increase productivity, accountability, quality, and customer satisfaction (Jelenic, 2011). Therefore, it can be said that if the company wants to have satisfied customers, it must have satisfied employees to serve them. Also, the company's goal is to keep employees satisfied within the company for as long as possible. Loyal and satisfied employees care about corporate values and improve business processes.

\subsection{The Studies that Focused on Links between Employee Well-Being and Balanced Scorecard}

Argan (2018) has examined relationships among well-being, leisure satisfaction, life satisfaction, and happiness and the result of the study was there is a significant relationship among constructs of well-being, satisfaction with life, and leisure and happiness. (Buyukbay, 2017) in has explored a proposal of a new employee well-being model of employee wholeness. According to the research analysis results, career success, emotional intelligence, psychological capital, and engagement are among the highest dimensions to explain employees' well-being, as well as in predicting work performance. (Claypool, 2017) study on organizational Success: How the Presence of Happiness in the Workplace Affects Employee Engagement that Leads to Organizational Success was based on a quantitative, correlational research design, the results of the test showed happiness in the workplace engagement that leads to organizational success. The strength of the relation is moderate: The collected data shows a positive correlation between happiness and engagement of the employee well-being at work. The positive correlation between happiness and engagement shows that happy employees are more likely to be engaged, a state that would improve productivity and hence ensure the organization would continue to develop. Hoang Ho (2019) has investigated Human resource management systems, employee well-being, and firm performance from the mutual gains and critical perspectives: The well-being paradox. The result of the study showed that employee well-being based on commitment and engagement had a significant and positive association with firm performance. Chandra (2016) study to test the influence of leadership styles, work environment, and job satisfaction of employees on performance result showed that the leadership style has an impact on performance, the work environment also has an impact on performance, job satisfaction has an impact on performance, and leadership style, work environment and job satisfaction of influential performance significant. Kairu (2013) study they aim to investigate "Effects of balanced scorecard on performance of firms in the service sector", the result of the study showed BSC developed employees' skills and performance which led to increased efficiency in their internal business processes. This led to improved customer satisfaction and increased market share, which in turn led to an increase in the firm's profitability. It was affirmed that increased profitability boosted the other functions of the firms which im-proved rewards to employees and more participation in corporate social responsibilities. It also gave the firms a positive public image and increased competitiveness. LEMMA (2018) the study aimed to investigate "An assessment on the implementation of BSC concerning employee performance: the result of the study showed the implementation of BSC has increased organizational performance and employee well-being. Narayanamma (2017) 'A study on Impact of BSC implementation in Job Satisfaction of Employees in Selected Public and Private Sector study result showed that there is a positive correlation between the balanced scorecard and job satisfaction. The better is the implementation of a balanced scorecard the high will be the job satisfaction. OPIYO' (2010) study as Influence of BSC on Employee Job Satisfaction: A survey of Cooperative Bank of Kenya Ltd result showed that job content (interest, prestige, and independence). Pay and Interpersonal relationships were the most motivators at the workplace The employees feeling about the jobs to a large extent were the relationships they have with other people at work, the actual job itself, the degree to which they feel 'motivated' by your job. the style of supervision that your superiors use, the extent to which you may identify with the public image or goals of your organization, current career opportunities, the feeling have about the way you and your efforts are valued, the kind of work or tasks that you are required to perform and the degree to which you feel that you can personally develop or grow in the job.

\section{Discussion and Implications for Human Research Management}

When reviewing the empirical evidence base for the Impact of BSC on Employee well-being, there were no more 
empirical studies that met the inclusion criteria. The study was wide-ranging, but the volume of research could have been significantly reduced if it had been tighter. There is a substantial framework of research evidence in which well-being is defined as life satisfaction, subjectively important, rewarding, or life satisfaction consistent with personal values. There is also research that defines employee well-being in many ways, such as meaningful work or the fit between an individual's job and personality. It has been shown that articles adopting quantitative methods usually use 6 different statistical methods to measure results, the majority of which are used fully in only one or two studies.

In most studies, organizational commitment and work engagement are examined under the same heading as if their meaning is same. However, (Fisher, 2010) work engagement is more based on positive experiences in the workplace such as vitality, motivation, mood, leader behaviors, feedback and employee relations.

In most studies of BSC practice, the results have mostly concentrated on three perspectives outcomes: financial, internal process, and customer perspectives (Chih-Chao Chung, 2016; Assiri, Zairi, \& Eid, 2006; Davis, 2003; Keller, 2011; Lueg, 2015; Malmi, 2001; Sirait, 2018; Soderberg, 2017; Thananchayana, 2018). The most important finding of this study is learning and growth perspective is a key factor to HR development and employee wellbeing. There are limited studies on the learning and growth perspective which is the most important perspective of BSC.

The weight of evidence the study reviewed suggests that employees are more likely to experience positive feelings when they connect to diverse sources of performance measurement systems or HR strategies rather than simply one. Based on the literature review HR strategies are mostly focused on employee retention, positive management, leadership style, job satisfaction, and leisure activities (Chandra \& Priyono, 2016; Jardon, 2019; Kilinc, 2019; Liu, 2010; Luciano, Mathieu, \& Ruddy, 2014; Manning, 2016; Mira, 2019; Morgan, 2015; Pauliené, 2012; Purnamasari \& Tridayanti, 2020; Skrzypczyńska, 2014; Voegtlin, Patzer, \& Scherer, 2012; Zbierowskia, 2014).

To reap the full benefits of the Balanced Scorecard approach, organizations should work harder to bring employees at all levels together through this method. The study explored the role of the balanced scorecard in increasing employee satisfaction and well-being. The empirical studies have demonstrated that there is a significant, strong positive correlation between employees' satisfaction with their company and employee productivity and customer loyalty, and a strong negative correlation with staff turnover.

The collected data shows a positive correlation between happiness and the performance of the employee. The positive correlation between happiness and engagement, job satisfaction, and commitment shows that happy employees are more likely to be engaged, a state that would improve productivity and hence ensure the organization would continue to develop. The results of the study show that happiness in the workplace is also crucial in keeping an employee productive. Efficiency is an important issue in organizational development; as a result, there is a need to ensure that employees are efficient in their work schedules. A passion for work is perceived as an incentive to work hard, which means employees are extra mindful at work to produce meaningful work.

The learning and growth perspective, which is one of the balanced scorecard perspectives, is of great importance for the satisfaction and well-being of the employee, who is the key factor in organizational success. This perspective helps increase value for the organization by improving business processes and people. The learning and growth perspective essentially means the quality of human resources in the organ. Organizations are focused on job satisfaction, organizational commitment, and the ability to increase productivity in the organization. Hence employee feelings and attitudes are important for satisfaction level. Finding's statement describing the employees feeling about the jobs to a large extent were:

- The relationships you have with other people at work,

- The actual job itself,

- The degree to which you feel 'motivated' by your job,

- The style of supervision that your superiors use,

- The extent to which you may identify with the public image or goals of organizthe ionization,

- The current career opportunities,

- The feeling you have about the way you and your efforts are valued,

- The kind of work or tasks that you are required to perform and

- $\quad$ The degree to which you feel that you can personally develop or grow in a job.

Employee commitment, job satisfaction, and work engagement are the three vital components of employee well- 
being. The present article intends to develop the issue by ascertaining the association between BSC and these three constructs of employee well-being. The finding establishes a Balanced Scorecard as a 'necessary' condition for employee well-being. This indicates that statistically, it is a benefit to organizational commitment, job satisfaction, and work engagement balance satisfaction with the Balanced Scorecard. The present study is perhaps one of the important studies to explore the relationship between BSC and employee well-being. The paper suggests that for $\mathrm{BSC}$ to institutionalize incorporate vision, mission, policy, and practices, the employee must take initiative and thus realize employee well-being in all areas of the organization. This will help employees to realize the meaning of a job, they have positive feelings in the workplace, experience team feeling, appreciate results without feverishness, and understand organizational commitment. These all are intended to increase the productivity of the organization. Organizations should develop positive organizational behavior through the BSC strategy that helps employees to realize their true potential. And then this potential will be channelized to the appropriate direction of organizational effectiveness. Future researchers may further explore a new perspective of BSC for organizational happiness by conceptualizing and measuring the workplace using both qualitative and quantitative approaches.

\section{References}

Andrews, F., \& Withey, S. (1976). Social Indicators of Well-Being. Americans Perceptions of Life Quality. New York: Plenum Press.

Argan, M. (2018). Examining Relationships Among Well-being, Leisure Satisfaction, Life Satisfaction, and Happiness. International Journal of Medical Research \& Health Sciences, 27(4), 49-59.

Assiri, A., Zairi, M., \& \& Eid, R. (2006). How to profit from the balanced scorecard. An implementation roadmap. Industrial Management and Data Systems, 106(7), 937-952.

Balc1, F. (2011). An Investigation on the Relationship Between Psychological and Subjective Well-Being and Religious Beliefs (pp. 72-80). Master Thesis, Uludağ University, Institute of Social Sciences, Bursa.

Bernice, L., \& Neugarten, R. (1961). The Measurement of Life Satisfaction. Journal of Gerontology, 16(2), 134143.

Boehm, J. (2008). Does happiness promote career success? Journal of Career Assessment, 5, 101-11.

Boehm, J. K., \& Lyubomirsky, S. (2008) Does happiness promote career success? Journal of Career Assessment. https://doi.org/10.1177/1069072707308140

Bradbury, H. L. (2000). Relationality in organizational research: Exploring the space between. Organization Science, 11(5), 551-564.

Buyukbay, S. (2017). Proposal of a new employee well-being model: Employee Wholeness (pp. 5-390). Ph.D. Thesis -Bahcesehir University.

Cantril, H. (1965). The Pattern of Human Concerns. New Brunswick: Rutgers University Press,

Chandra, T. (2016). The Influence of Leadership Styles, Work Environment and Job Satisfaction of Employee Performance-Studies in the School of SMPN 10 Surabaya. International Education Studies, 9(1), 131-142.

Chih-Chao, C. (2016). A Balanced Scorecard of Sustainable Management in the Taiwanese Bicycle Industry: Development of Performance Indicators and Importance Analysis. Management Accounting, 8(6), 1-21.

Christakis, N. A., Fowler, J. H. (2009). Dynamic Spread of Happiness in a Large Social Network: Longitudinal Analysis Over 20 Years in the Framingham Heart Study. British Medical Journal, 3, 1-31.

Christakis, N., \& Fowler, J. (2008). Dynamic spread of happiness in a large social network. BMJ Clinical Research, 337. https://doi.org/10.1136/BMJ.a2338, 2200-2338

Claypool, K. K. (2017). Organizational Success: How the Presence of Happiness in the Workplace Affects Employee Engagement that Leads to Organizational Success. Ph.D. Thesis -Pepperdine University-Published by ProQuest LLC /United States.

Cobbold, I., Lawrie, G., \& Issa, K. (2004). Designing a strategic management system using the third-generation balanced scorecard: A case study. International Journal of Productivity and Performance Management, 53(7), $624-633$.

Coe, N., \& Letza, S. (2014). Two decades of the balanced scorecard: A review of developments. Poznan University of Economics Review, 14(1), 63-75.

Davis, D., \& Doley, B. (2008). The Learning Organizations and Its Dimensions as Key Factors in Firms Perspective. Human Resource Development International, 11(1), 51-66. 
Davis, S. A. (2003). An Investigation of the effect of BSC implementation on financial performance. Management Accounting Research, 15(2), 135-153.

Deming, W. E. (2000). A theory of management based on his famous 14 Points for Management (p. 524).

Diener, E. (1984). Subjective well-being. Psychological Bulletin, 95, 542-575.

Diener, E. (1994). Assessing subjective well-being: Progress and opportunities. Social Indicators Research, 31, $103-157$.

Diener, E. (1999). Subjective well-being: Three decades of progress. Psychological Bulletin, 125, 276- 302.

Diener, E. (2000). Money and happiness: Income and subjective well-being across nations. In E. Diener \& E. M. Suh (Eds.), Subjective well-being across cultures. Cambridge, MA: MIT Press.

Diener, E. (2000). Subjective well-being: The science of happiness and a proposal for a national index. American Psychologist, 55(1), 34.

Diener, E. (2004). Beyond Money. Psychological Science in the Public Interest, 5(1), 1-31.

Diener, E. S. (1997). Recent findings on subjective well-being. Indian Journal of Clinical Psychology, 4(2), 2441.

Diener, E., Emmons, R. L., \& Sharon, G. (1985). The Satisfaction with Life Scale. Journal of Personality Assessment, 6, 71-75.

Diener, E; \& Seligman, M. E. (2002). Very Happy People. Psychological Science, 13(1), 81-84. https://doi.org/10.1111/1467-9280.00415

Epstein, \& Manzoni, J. (1997). The balanced scorecard and tableau de bord: Translating strategy into action. Management Accounting, 79(2), 28-36.

Erdogan, A. (2013). Relations between Balanced Scorecard, Job Satisfaction, and Organizational Commitment: Central Organization of the Ministry of Finance. PhD Thesis-İnönü Üniversitesi Sosyal Bilimler Enstitüsü.

Figge, F., \&., \& Hahn, T. S. (2002). The Sustainability Balanced Scorecard-Management to Business Strategy. Business Strategy and the Environment Bus. Strat. Env. https://doi.org/10.1002/bse.339

Fisher, C. D. (2010). Happiness at Work, School of Business, Bond University, Australia. International Journal of Management Reviews, 12(4), 384-412.

Ghalayini, A. (1996). The changing basis of performance measurement. International Journal of Operations \& Production Management, 5(3), 58-79.

Gultekin, Z. (2019). The Mediating Role of Occupational Commitment in the Effect of Job Insecurity on Psychological Well-Being and Performance? Thesis of Abc University.

Heathwood, C. (2006). Desire Satisfaction and Hedonism. Philosophical Studies, 128. https://doi.org/10.1007/s11098-004-7817-y

Hoang Ho, K. (2019). Human resource management systems, employee well-being, and firm performance from the mutual gains and critical perspectives: The well-being paradox. Human Resource Management. https://doi.org/10.1002/hrm.21990-2019

Jardon, C. M. C. (2019). Leadership and Organizational Culture in the Sustainability of Subsistence Small Businesses: An Intellectual Capital Based View. Licensee MDPI, Basel, Switzerland, 2(9), 1-15.

Jelenic, D. (2011). The Importance of Knowledge Management in Organizations- With Emphasis on the BSC Learning and Growth Perspective. Faculty of Economics, University of Nis, Republic of Serbia.

Joshanloo, M. (2012). A Comparison of Western and Islamic Conceptions of Happiness. Journal of Happiness Studies, 14(6), 1857-1874.

Kairu, E. W. (2013). Effects of balanced scorecard on performance of firms in the service sector. European Journal of Business and Management, 9(5), 81-87.

Kaplan, R. (1996). Using the Balanced Scorecard as a Strategic Management System. Harvard Business Review, 74(1), 75-85.

Kaplan, R. (2000). Have trouble with your strategy? Then map. Harvard Business Review, 78(5), 167-176.

Kaplan, R. N. (2010). Managing alliances with the balanced scorecard. Harvard Business Review, 88(1-2), 114120. 
Kaplan, R., \& Norton, D. (1996). Translating Strategy into Action - The Balanced Scorecard. Massachusetts: Harvard Business School Press.

Kassahun, T. (2010). Rethinking institutional excellence in Ethiopia: adapting and adopting the balanced scorecard (BSC) model. Journal of Business and Administrative Studies, 2(1), 22-51.

Keller, S. (2011). Beyond performance: How great organizations build ultimate competitive advantage. Hoboken, NJ: John Wiley \& Sons.

Keyes, C. L., Ryff, C. D., \& Shmotkin, D. (2002). Optimizing Well-Being: The Empirical Encounter of Two Traditions. Journal of Personality and Social Psychology, 82(6), 1007-1022.

Kilinc, U. (2019). Perceptions of Authentic Leadership and Work Happiness: A study of Hotel Business in Ankara. The Journal of Faculty of Economics and Administrative Sciences, 793-811.

Krekel, C., Ward, G., \& De Neve, J. (2019). Employee Wellbeing, Productivity, and Firm Performance. Butterfly AI, Psychological Technologies, and the Gallup Organization, 1-49.

Kun, A., \& Gadanecz, P. (2019). Workplace happiness, well-being, and their relationship. Current Psychology. https://doi.org/10.1007/s12144-019-00550-0, 1-15.

Lemma, A. (2018). An assessment on the implementation of BSC concerning employee performance: The case of Oromia Regional Health Bureau. Master Thesis of St. Mary's University.

Levin, K. A., \& Currie, C. (2014). Reliability and Validity of an Adapted Version of the Cantril Ladder for Use with Adolescent Samples. Social Indicators, 1047-1063.

Liu, J. S. L. (2010). Transformational leadership and employee well-being: the mediating role of trust in the leader and self-efficacy. Applied Psychology, 59(3), 454-479.

Lucas, R. E., \& Dyrenforth, P. S. (2008). Explaining the extraversion/positive effect relation: Sociability cannot account for extraverts' greater happiness. Journal of Personality, 76(3), 385-414.

Luciano, M. M., \& Mathieu, J. E., \& Ruddy, T. M. (2014). Leading multiple teams: Average and relative external leadership influences on team empowerment and effectiveness.

Lueg, R. (2015). Success Factors in Balanced Scorecard Implementations - A Literature Review. Management Revue, 26(4), 306-327.

Lyubomirsky, S., \& Lepper, H. S. (1999). A Measure of Subjective Happiness: Preliminary Reliability and Construct Validation. Social Indicators Research, 46, 137-155.

Lyubomirsky, S., \& Ross, L. (1997). Hedonic consequences of social comparison: A contrast of happy and unhappy people. Journal of Personality and Social Psychology, 73, 1141-1157.

Malina, M., \& Selto. (2001). Communicating and Controlling Strategy: An Empirical Study of the Effectiveness of the Balanced Scorecard. Journal of Management Accounting Research, 13(1), 1-56.

Malmi, T. (2001). Balanced scorecards in Finnish companies: a research note. Management Accounting Research, $12(2), 207-220$

Manning, J. (2016). The influence of nurse manager leadership style on staff nurse work engagement. The Journal of Nursing Administration, 46(9), 438-443.

Marwa, R. M. (2019). Balanced Scorecard development over the last 26 years. IOSR Journal of Business and management, 21(1), 13-16.

Mayer, D. (2012). A positive lens on organizational justice: Toward a moral, constructive and balanced approach to reactions to third-party (in)justice. In Cameron, K.S., Spreitzer, G.M. (Eds.), The Oxford handbook of positive organizational scholarship. Oxford/New York: Oxford University Press.

Meisenberg, G., \& Woodley, M. (2015). Gender Differences in Subjective Well-Being and Their Relationships with Gender Equality. Journal of Happiness Studies, 16(6), 1539-1555.

Messersmith, J. G. W. (2011). Unlocking the black box: Exploring the link between high-performance work systems and performance. Journal of Applied Psychology, 96(6).1105-1118.

Miao, F., Minkyung, K., \& Oishi, S. (2013). Subjective Well-being. Oxford, UK: Oxford University Press.

Mira, M. A. (2019). The mediating role of authentic leadership between the relationship of employee training and employee performance. Management Science Letters, 9(3), 381-388. 
Molina, M. Á. (2014). Does the balanced scorecard adoption enhance the levels of organizational climate, employees' commitment, job satisfaction, and job dedication? Management Decision, 56(5), 983-1010.

Morgan, L. (2015). The influence of school leadership practices on classroom management, school environment, and academic underperformance. Unpublished Doctoral Dissertation, Walden University: Florida.

Myers, D. G., \& \& Diener, E. (1995). Who Is Happy? Psychological Science, 6(1), 10-19.

Narayanamma, P. L. (2017). A study on Impact of BSC implementation in Job Satisfaction of Employees in Selected Public and Private Sector. Department of Management Studies, Vignan's University, Guntur.

Neely, A., \& Mills, J., Platts, K., Richards, H., Gregor, M., Bourne, \& Kennerley. (2000). Performance measurement system design: developing and testing a process-based approach. International Journal of Operations \& Production Management, 10-20.

Nesbit, P. (2012). The role of self-reflection, emotional management of feedback, and self-regulation processes in self-directed leadership development. Human Resource Development Review, 11(2), 203-226.

Neugarten, B. (1961). The Measurement of Life Satisfaction. 134-143.

Nikolaev, B. (2016). Does Higher Education Increase Hedonic and Eudaimonic Happiness? Journal of Happiness Studies, 19(4), 1-22.

Opiyo, R. (2010). Influence of BSC on Employee Job Satisfaction: A survey of Cooperative Bank of Kenya Ltd. Master Thesis of School of Business University of Nairobi.

Paulienè, R. (2012). Transforming leadership styles and knowledge sharing in a multicultural context. Business, Management, and Education, 10(1), 91-109.

Pavot, W., Diener, E., \& Colvin, C. S. (1991). Further validation of the Satisfaction with Life Scale: Evidence for the cross-method convergence of well-being measures. Journal of Personality Assessment, 49, 71-75.

Porter, L. R. (1974). Organizational commitment, job satisfaction, and turnover among psychiatric technicians. Journal of Applied Psychology, 59, 603-609.

Potapov, D. V. (2016). Happiness and the city: An empirical study of the interaction between subjective well-being and city satisfaction. Journal of Place Management and Development, 9(3), 313-330.

Pryce-Jones, J. (2010). Happiness at work: Maximizing your psychological capital for success (pp. 1-59). The United Kingdom, Oxford: Wiley-Blackwell.

Purnamasari, B. E., \& Tridayanti, R. H. (2020). Analysis of Influence of Compensation and Leadership Style to Employee Performance PT. Feva Indonesia. Quantitative Economics and Management Studies, 1(1), 9-24.

Ryan R. M., \& Deci, M. L. (2001). On happiness and human potentials: A review of research on hedonic and eudemonic well-being. Annual Review of Psychology, 52, 141-166.

Ryff, C. (1985). Adult Personality Development and the Motivation for Personal Growth. In Kleiber, D. and Maher, M. (Eds.), Advances in Motivation and Achievement: Motivation and Adulthood (pp. 55-92). Greenwich.: JAI Press.

Ryff, C. D. (1982). Successful aging: A developmental approach. Gerontologist, 22(2),209-214.

Ryff, C. D. (1989). Beyond Ponce de Leon and life satisfaction: New directions in quest of successful aging. International Journal of Behavioral Development, 12, 35-55.

Ryff, C. D. (1995). The structure of psychological well-being revisited. Journal of Personality and Social Psychology, 69, 719-727.

S, C. N. (2014). Two decades of the balanced scorecard: A review of developments. Poznan University of Economics Review, 14(1), 63-75.

Schulz, K. P. (2005). Learning in complex organizations as practicing and reflecting: A model development and application from a theory of practice perspective. Journal of Workplace Learning, 17(8), 493-507.

Seligman, M. (2011). Authentic happiness. New York: Atria Paperback.

Seligman, M. (2011). Flourish A visionary new understanding of happiness and well-being. New York.: Simon \& Schuster,

Seligman, M. E. (2000). Positive psychology: An introduction. American Psychologist, Positive psychology: An introduction. American Psychologist, 55(1), 5-14. 
Seligman, M. P. (2002). Authentic Happiness: Using the new positive psychology to realize your potential for lasting fulfillment. New York: Free Press.

Simbolon, S. M. (2018). Performance Management Systems based on the Balanced Scorecard Framework: The Case of Indonesian Customs and Excise Organizations. The University of Manchester for the degree of Doctor of Philosophy, 1-360.

Sirait, B. T. (2018). After Balanced Scorecards Implementation: What Changes Does It Bring? a Case of Ministry of Foreign Affairs Indonesia. Management Journal, 2(9), 6-7.

Skrzypczyńska, K. (2014). Social responsibility of companies operating in Poland. Journal of Corporate Responsibility and Leadership, 1(1), 71-84.

Soderberg, M. J. (2017). The Balanced Scorecard: Structure and Use in Canadian Companies. Canadian Business Journal, 2(4), 3-4.

Sparr, J. A. (2008). Fairness perceptions of supervisor feedback, LMX, and employee well-being at work. European Journal of Work and Organizational Psychology, 17(2), 198-225.

Stankiewicz, M. (2015). Modeling of the key areas of Positive Organizational Potential as a manifestation of positive management paradigm operationalization. Torun Business Review, 14(1), 21-35.

Stankiewicz, M. J. (2015). Modeling of the key areas of Positive Organizational Potential as a manifestation of positive management paradigm operationalization. Torun Business Review, 14(1), 21-35.

Stankiewicz, M. N. (2014). Positive Management. Managing the Key Areas of Positive Organisational Potential for Company Success. Journal of Business Ethics, 11(6), 366.

Sudolska, A. A. (2015). Building a model of successful collaborative learning for company innovativeness.

Tennant, C., \& Roberts, P. (2001). Hoshin Kanri: a tool for strategic policy deployment. Knowledge and Process Management, 8(4), 262-269.

Thananchayana, K. (2018). Successful Implementation of the Balanced Scorecard in a Telecommunications Firm: An Institutional Theory Analysis. Colombo Business Journal, 9(2), 26-52.

Veenhoven, R. (1994). Is happiness a trait: Tests of the theory that a better society does not make people any happier? Social Indicators Research, 32, 101-160.

Veenhoven, R. (1996). Study The Study of Life Satisfaction, Comparative Study of Satisfaction with Life in Europe. Eötvös University Press.

Veenhoven, R. (1996). Study The Study of Life Satisfaction, Comparative Study of Satisfaction with Life in Europe.

Veenhoven, R. (2009). How do we assess how happy we are? Cheltenham UK: Edward Elgar Publishers.

Voegtlin, C., Patzer, M., \& Scherer, A. G. (2012). Responsible leadership in global business: A new approach to leadership and its multi-level outcomes. Journal of Business Ethics, 105(1), 1-43.

Waterman, A. (1993). Two conceptions of happiness: contrasts of personal expressiveness (eudaimonia) and hedonic enjoyment. J. of Pers. Soc. Psychol. 64(6), 78-91.

Watson, D. C., \& Tellegen, A. (1988). Development and validation of brief measures of positive and negative affect: The PANAS scales. Journal of Personality and Social Psychology, 54.

Weiss, H. M. (2002). Deconstructing job satisfaction: Separating evaluations, beliefs, and affective experience. Human Resource Management Review, 12, 173-194.

Zbierowskia, P. G. (2014). Positive Leadership: Its Nature Antecedents and Consequences. Journal of Positive Management, 5(1), 85-99.

Zevnik, L. (2014). Critical Perspectives in Happiness Research the Birth of Modern Happiness. Switzerland.: Springer International Publishing. 


\section{Appendix A: List of empirical studies}

\begin{tabular}{|c|c|c|c|c|c|}
\hline Field & Year & Author & Proposal & Publication & indings \\
\hline $\begin{array}{l}\text { Employee } \\
\text { Well-being }\end{array}$ & 2017 & Buyukbay, S.E & $\begin{array}{l}\text { Proposal of a new } \\
\text { employee well- } \\
\text { being model: } \\
\text { Employee } \\
\text { Wholeness }\end{array}$ & $\begin{array}{l}\text { Ph.D. Thesis } \\
\text { Bahcesehir } \\
\text { University }\end{array}$ & $\begin{array}{l}\text { According to the research analysis results, career success (,872 } \\
\mathrm{p}<0,001) \text {, emotional intelligence }(, 762 \mathrm{p}<0,001) \text {, psychological } \\
\text { capital }(, 728 \mathrm{p}<0,001) \text {, and engagement }(, 720 \mathrm{p}<0,001) \text { are among } \\
\text { the highest dimensions to explain employees' well-being, as well } \\
\text { as in predicting work performance. According to the confirmatory } \\
\text { factor and path analyses, it is observed that among its dimensions, } \\
\text { meaning (,910 } \mathrm{p}<0,001) \text { under career success, motivation (,773 } \\
\mathrm{p}<0,001) \text { under emotional intelligence, hope (,980 } \mathrm{p}<0,001) \text {, and } \\
\text { self-efficacy }(, 976 \mathrm{p}<0,001) \text { under psychological capital, and work } \\
\text { enjoyment }(, 960 \mathrm{p}<0,001) \text { under engagement have been the highest } \\
\text { factors to explain their respective dimensions. }\end{array}$ \\
\hline $\begin{array}{l}\text { Employee } \\
\text { Well-being }\end{array}$ & 2017 & $\begin{array}{l}\text { Claypool, } \\
\text { Kevin K. }\end{array}$ & $\begin{array}{l}\text { Organizational } \\
\text { Success: How the } \\
\text { Presence of } \\
\text { Happiness in the } \\
\text { Workplace } \\
\text { Affects } \\
\text { Employee } \\
\text { Engagement that } \\
\text { Leads to } \\
\text { Organizational } \\
\text { Success }\end{array}$ & $\begin{array}{l}\text { Ph.D. Thesis - } \\
\text { Pepperdine } \\
\text { University- } \\
\text { Published by } \\
\text { ProQuest LLC } \\
\text { /United States }\end{array}$ & $\begin{array}{l}\text { The results of the test showed happiness in the workplace and } \\
\text { employee engagement that leads to organizational success in both } \\
\text { private elementary and secondary } \mathrm{K}-12 \text { teachers was significantly } \\
\text { positively correlated to ( } \mathrm{p}=0.01, \mathrm{r}=0.36 \text { ). This was because the } \\
\text { p-value was less than the level of significance of } 0.05 \text {. The positive } \\
\text { correlation suggested that employee engagement in the workplace } \\
\text { would increase if happiness in the workplace also increased. The } \\
\text { strength of the correlation is moderate: The collected data shows a } \\
\text { positive correlation between happiness and engagement of the } \\
\text { employee. This is a significant finding as it can be used by } \\
\text { organizations to fast-track their development by ensuring that } \\
\text { employees are happy. The positive correlation between happiness } \\
\text { and engagement shows that happy employees are more likely to be } \\
\text { engaged, a state that would improve productivity and hence ensure } \\
\text { the organization would continue to develop. }\end{array}$ \\
\hline $\begin{array}{l}\text { Employee } \\
\text { Well-being, } \\
\text { Org } \\
\text { Performance }\end{array}$ & 2019 & $\begin{array}{l}\text { Christian } \\
\text { Krekel } \\
\text { \&George } \\
\text { Ward\&Jan- } \\
\text { Emmanuel De } \\
\text { Neve }\end{array}$ & $\begin{array}{l}\text { Employee } \\
\text { Wellbeing, } \\
\text { Productivity, and } \\
\text { Firm } \\
\text { Performance }\end{array}$ & $\begin{array}{l}\text { Butterfly AI, } \\
\text { Psychological } \\
\text { Technologies, and } \\
\text { the Gallup } \\
\text { Organization }\end{array}$ & $\begin{array}{l}\text { Result: significant, strong positive correlation between employees' } \\
\text { satisfaction with their company and employee productivity and } \\
\text { customer } \\
\text { loyalty, and a strong negative correlation with staff turnover. } \\
\text { Ultimately, higher wellbeing at work is positively correlated with } \\
\text { more business-unit level profitability }\end{array}$ \\
\hline $\begin{array}{l}\text { Employee } \\
\text { Well-being, } \\
\text { Org } \\
\text { Performance }\end{array}$ & 2019 & $\begin{array}{l}\text { Hoang Ho, \& } \\
\text { Kuvaas Bård }\end{array}$ & $\begin{array}{l}\text { Human resource } \\
\text { management } \\
\text { systems, } \\
\text { employee well- } \\
\text { being, and firm } \\
\text { performance } \\
\text { from the mutual } \\
\text { gains and critical } \\
\text { perspectives: The } \\
\text { well-being } \\
\text { paradox }\end{array}$ & $\begin{array}{l}\text { Human Resource } \\
\text { Management. DOI: } \\
\text { 10.1002/hrm.21990- } \\
2019 \quad \text { Wiley } \\
\text { Periodicals, Inc. }\end{array}$ & $\begin{array}{l}\text { Human resource management systems, employee well-being, and } \\
\text { firm performance from the mutual gains and critical perspectives: } \\
\text { The well-being paradox. Based on a sample of } 14,384 \text { employees } \\
\text { nested within } 1,347 \text { firms: two variables, organizational } \\
\text { commitment, and job satisfaction, were used as proxies for } \\
\text { happiness. Organizational commitment (alpha =.77) was measured } \\
\text { by a well-established scale by Meyer and Allen in } 1997 \text { : } \\
\text { "employees share the organization's values, feel loyal to the } \\
\text { organization, and e proud to tell people about the organization. } \\
\text { scale ( } 1=\text { strongly disagree; } 5=\text { strongly agree). ob satisfaction } \\
\text { (alpha =.87) was measured by seven items, reflecting seven facets } \\
\text { of work, which have been used in several WERS-based studies: } \\
\text { "employee satisfaction with influence, with achievement from } \\
\text { work, with job security, with the training, received, with } \\
\text { involvement in decision-making," and with the work itself" ( } 1= \\
\text { very dissatisfied; } 5=\text { very satisfied). Conclusion: In isolation, the } \\
\text { employee well-being had a significant and positive association } \\
\text { with firm performance (b }=.05, p<.001)\end{array}$ \\
\hline
\end{tabular}




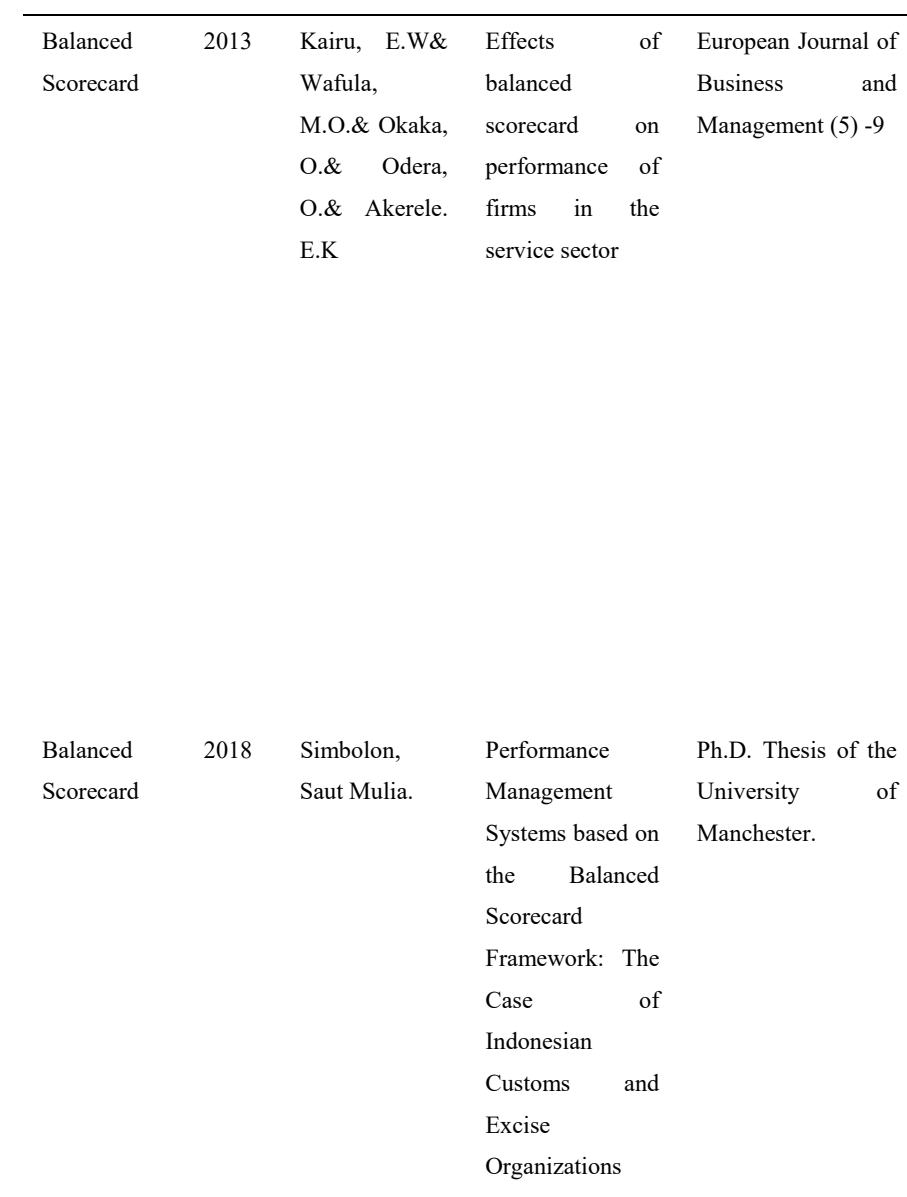

BSC and 2018 LEMMA, A Employee Well-being

$\begin{array}{ll}\begin{array}{l}\text { An assessment on } \\ \text { the }\end{array} & \text { Master Thesis of ST. } \\ \text { implementation } & \text { UNIVERSITY } \\ \text { of BSC } & \\ \text { concerning } & \\ \text { employee } & \\ \text { performance: The } \\ \text { case of Oromia } \\ \text { Regional Health } \\ \text { Bureau }\end{array}$

The results indicate that all the drivers of success had a mean value above the expected mean. Customer satisfaction had the highest mean value of 4.81 , improved internal business processes had 4.14 , and learning, growth, and innovation had a mean of 4. 11, while highly motivated staff had the lowest mean of 3.89. This indicates that, on average, all the four measures are viewed to be more than important drivers of the firms' success. The four perspectives of the BSC are the most important drivers of a firm's success.

- All firms develop their employees' skills and performance which led to increased efficiency in their internal business processes. This led to improved customer satisfaction and increased market share, which in turn led to an increase in the firm's profitability.

- It was affirmed that increased profitability boosted the other functions of the firms which improved rewards to employees and more participation in corporate social responsibilities.

- It also gave the firms a positive public image and increased competitiveness.

The results of the growth curve modeling show that BSC implementation in all twelve organizations had a positive association with the customer satisfaction index $(0.07$ at $\rho<0.05)$ and a negative association with organization size $(-0.33$ at $\rho<0.1)$. - A positive correlation with state revenue collection (0.41), indicates that positive changes in state revenue collection resulted from the implementation of the BSC. - The growth curve analysis used data from customer satisfaction indices. Like the panel data regression results, the growth model analysis also found that there is a positive association (0.07) between BSC implementation and customer satisfaction index. The relationship between BSC implementation and Organization Commitment (OC) can be summarized thus: - Strategy translation has a negative and significant relationship with Organization Commitment $(\mathrm{OC}(\beta=-$ 0.36 at $\rho<0.05)$; - Strategy has a positive and significant relationship with $\mathrm{OC}(\beta=0.33$ at $\rho<0.01)$; - Leadership involvement has a positive and significant relationship with OC $(\beta=0.63$ at $\rho<0.01)$ : The better the leadership involvement through BSC implementation, the more employees' organizational commitment will increase - The employees' roles are positively correlated with organizational commitment.

Result summary, the aggregated mean calculated for the five statements under the subject 'Leadership' reads 3.41. Employee Competency WA has been calculated as 3.72 . The 3.72 weighted average mean calculated for all the statements under 'Employee Competency' proves that the details have been included to truly evaluate the overall competency of the respondents about the implementation of the BSC. They are positively impacting the dimension confirming that they are relevant to evaluating the construct. As the final element under this variable, respondents were assessed on whether the practices of the reward system have nothing to do with the BSC implementation. In general, what the whole thing shows is that the implementation of BSC at least has helped the Bureau in establishing a planning and measurement system that drew a tangible experience among the general staff. The BSC has somehow helped them to give due attention to the customers they are serving. There is a huge gap in monitoring performances and forwarding timely feedback. Looking at these, it is valid to conclude that there is a substantial gap in leadership 
commitment.

$\begin{array}{llll}\text { BSC and 2010 OPIYO, R.M. } & \text { Influence of BSC } & \text { Master Thesis of } \\ \text { Employee } & \text { on Employee Job } & \text { School of Business } \\ \text { Well-being } & \text { Satisfaction: A } & \text { University of } \\ & \text { survey of Nairobi } \\ & \text { Cooperative } & \\ & \text { Bank of Kenya } \\ & \text { Ltd }\end{array}$

Result of Study: $60.9 \%$ of the respondents thought that cooperative bank staff had accepted the use of balanced scorecard in the bank while a significant $39.1 \%$ thought that balance scorecard has not been accepted in the bank. AS indicated in below $69.6 \%$ of the respondents thought that balance scorecard reflects a good measure for measuring performance based on the four perspectives. From the findings the respondents identified the following as the most motivators at the workplace; Job content: interest, prestige, and independence (mean of 3.9130). Pay (mean of 3.6043) and Interpersonal relationships (mean of 3.5435). To a moderate extent, the following were the motivators; prospects, that is promotion \& job security, (mean of 3.1957), How hard the job is (mean of 3.1522), and Flours of work (mean of 2.8913). Conclusion: The study found that

- BSC use in the bank was straightforward and user-friendly and that balance scorecard reflects a good measure for measuring performance based on the four pillars as entrenched in the strategic plan of the bank. - It was apparent that operational management and Monitoring and evaluation were the most highly used balances scorecards in the bank.

- While Job content (interest, prestige, and independence). Pay and Interpersonal relationships were the most motivators at the workplace.

- The employee's feelings about the jobs to a large extent were the relationships you have with other people at work, the actual job itself, the degree to which you feel 'motivated' by your job. the style of supervision that your superiors use, the extent to which you may identify with the public image or goals of your organization, current career opportunities, the feeling have about the way you and your efforts are valued, the kind of work or tasks that you are required to perform and the degree to which you feel that you can personally develop or groin job.

$\begin{array}{lllll}\text { BSC and } 2017 & \text { Narayanamma, } & \text { A study on } & \text { Department of } \\ \text { Employee } & \text { P. Lakshmi } & \text { Impact of BSC } & \text { Management } \\ \text { Well-being } & & \text { implementation } & \text { Studies, Vignan's } \\ & \text { in Job } & \text { University, Guntur } \\ & \text { Satisfaction of } \\ & \text { Employees in } \\ & \text { Selected Public } \\ & \text { and Private } \\ & \text { Sector }\end{array}$

There is a positive correlation between a balanced scorecard and job satisfaction. The better is the implementation of a balanced scorecard the high will be the job satisfaction. The hypothesis of a relationship between a balanced scorecard and job satisfaction was tested using simple linear regression. The regression results that the predictor variable contributes significantly and had a moderate impact on the Balanced Scorecard $(\mathrm{R} 2=0.119)$. The corresponding ANOVA value $(\mathrm{F}=74.893, \mathrm{p}=0.000)$ for the regression models had influenced the validation with Job Satisfaction. To derive full benefits from the scorecard approach companies must work harder to get employees at all levels on board with the method. The study investigated the role of a balanced scorecard in enhancing the job satisfaction of employees. The results revealed that there is a positive correlation between a balanced scorecard and job satisfaction. 


\section{Appendix B: Correlations list of empirical studies}

\begin{tabular}{|c|c|c|c|c|c|c|}
\hline $\begin{array}{l}\text { Relationship } \\
\text { Between } \\
\text { Dimensions }\end{array}$ & Correlation & Year & Authors & Study & Sample & Statistical Method \\
\hline $\begin{array}{l}\text { Job Satisfaction, } \\
\text { Organizational } \\
\text { Commitment, } \\
\text { Work } \\
\text { Engagement, and } \\
\text { Employee Well- } \\
\text { being }\end{array}$ & $\begin{array}{l}\text { Significant } \\
\text { (positive) }\end{array}$ & 2017 & Buyukbay, S.E & $\begin{array}{l}\text { Proposal of a new employee } \\
\text { well-being model: Employee } \\
\text { Wholeness }\end{array}$ & $\begin{array}{l}26 \text { professionals, most of whom } \\
\text { have more than } 15 \text { years of work } \\
\text { experience and are in executive } \\
\text { positions from } 5 \text { different } \\
\text { industries. }\end{array}$ & Exploratory Factor Analysis \\
\hline $\begin{array}{l}\text { Organizational } \\
\text { happiness, } \\
\text { Employee Well- } \\
\text { being }\end{array}$ & $\begin{array}{l}\text { Significant } \\
\text { (positive) }\end{array}$ & 2017 & $\begin{array}{l}\text { Claypool, } \\
\text { Kevin K. }\end{array}$ & $\begin{array}{l}\text { Organizational Success: How } \\
\text { the Presence of Happiness in } \\
\text { the Workplace Affects } \\
\text { Employee Engagement that } \\
\text { Leads to Organizational } \\
\text { Success }\end{array}$ & $\begin{array}{l}\text { The study used the data collected } \\
\text { from both private elementary and } \\
\text { secondary K-12 teachers. }\end{array}$ & $\begin{array}{l}\text { Data analyses were } \\
\text { conducted using Statistical } \\
\text { Package for Social Sciences } \\
\text { (SPSS) Version } 17.0\end{array}$ \\
\hline $\begin{array}{l}\text { Employee Well- } \\
\text { being, } \\
\text { Organizational } \\
\text { Performance }\end{array}$ & $\begin{array}{l}\text { Significant } \\
\text { (positive) }\end{array}$ & 2019 & $\begin{array}{l}\text { Christian } \\
\text { Krekel } \\
\text { \&George } \\
\text { Ward\&Jan- } \\
\text { Emmanuel De } \\
\text { Neve }\end{array}$ & $\begin{array}{l}\text { Employee Wellbeing, } \\
\text { Productivity, and Firm } \\
\text { Performance }\end{array}$ & $\begin{array}{l}339 \text { independent research studies, } \\
\text { including the wellbeing of } \\
1,882,131 \text { employees and the } \\
\text { performance of } 82,248 \text { business } \\
\text { units, originating from } 230 \\
\text { independent organizations across } \\
49 \text { industries in the Gallup client } \\
\text { database. }\end{array}$ & $\begin{array}{l}\text { Meta-Analysis of the Gallup } \\
\text { Employee Wellbeing } \\
\text { Database. }\end{array}$ \\
\hline $\begin{array}{l}\text { Employee Well- } \\
\text { being, Org } \\
\text { Performance }\end{array}$ & $\begin{array}{l}\text { Significant } \\
\text { (positive) }\end{array}$ & 2019 & $\begin{array}{l}\text { Hoang Ho, \& } \\
\text { Kuvaas Bård }\end{array}$ & $\begin{array}{l}\text { Human resource } \\
\text { management systems, } \\
\text { employee well-being, and } \\
\text { firm performance from the } \\
\text { mutual gains and critical } \\
\text { perspectives: The well-being } \\
\text { paradox }\end{array}$ & $\begin{array}{l}\text { Based on a sample of } 14,384 \\
\text { employees nested within } 1,347 \\
\text { firms: two variables, } \\
\text { organizational commitment, and } \\
\text { job satisfaction. }\end{array}$ & $\begin{array}{l}\text { Measured by seven items, } \\
\text { reflecting seven facets of } \\
\text { work, which have been used in } \\
\text { several WERS-based studies }\end{array}$ \\
\hline $\begin{array}{l}\text { BSC and } \\
\text { Organization } \\
\text { performance }\end{array}$ & $\begin{array}{l}\text { Significant } \\
\text { (positive) }\end{array}$ & 2013 & $\begin{array}{l}\text { Kairu, E.W\& } \\
\text { Wafula, } \\
\text { M.O.\& } \\
\text { Okaka, O.\& } \\
\text { Odera, O.\& } \\
\text { Akerele. E.K }\end{array}$ & $\begin{array}{l}\text { Effects of balanced scorecard } \\
\text { on performance of firms in } \\
\text { the service sector }\end{array}$ & $\begin{array}{l}\text { The population of the study } \\
\text { consisted of all the service } \\
\text { providing firms operating within } \\
\text { Kakamega Municipality, Kenya as } \\
\text { of December } 2007\end{array}$ & $\begin{array}{l}\text { Descriptive statistics were } \\
\text { used, with stratified random, } \\
\text { after stratification descriptive } \\
\text { statistics have been used. }\end{array}$ \\
\hline $\begin{array}{l}\text { BSC and } \\
\text { Organization } \\
\text { performance }\end{array}$ & $\begin{array}{l}\text { Significant } \\
\text { (positive) }\end{array}$ & 2018 & $\begin{array}{l}\text { Simbolon, Saut } \\
\text { Mulia. }\end{array}$ & $\begin{array}{l}\text { Performance Management } \\
\text { Systems based on the } \\
\text { Balanced } \\
\text { Framework: The Case of } \\
\text { Indonesian Customs and } \\
\text { Excise Organizations }\end{array}$ & $\begin{array}{l}\text { This study collected primary data } \\
\text { (survey questionnaires) from } \\
\text { twelve CEOs in Indonesia }\end{array}$ & $\begin{array}{l}\text { Confirmatory Factor } \\
\text { Analysis (CFA), Structural } \\
\text { Equation Modelling (SEM), } \\
\text { Panel Data Regression } \\
\text { modeling, and Growth curve } \\
\text { analysis. }\end{array}$ \\
\hline $\begin{array}{l}\text { BSC and } \\
\text { Organizational } \\
\text { Commitment }\end{array}$ & $\begin{array}{l}\text { Significant } \\
\text { (positive) }\end{array}$ & 2018 & $\begin{array}{l}\text { Simbolon, Saut } \\
\text { Mulia. }\end{array}$ & $\begin{array}{l}\text { Performance Management } \\
\text { Systems based on the } \\
\text { Balanced } \\
\text { Framework: The Case of } \\
\text { Indonesian Customs and } \\
\text { Excise Organizations }\end{array}$ & $\begin{array}{l}\text { This study collected primary data } \\
\text { (survey questionnaires) from } \\
\text { twelve CEOs in Indonesia }\end{array}$ & $\begin{array}{l}\text { Confirmatory Factor } \\
\text { Analysis (CFA), Structural } \\
\text { Equation Modelling (SEM), } \\
\text { Panel Data Regression } \\
\text { modeling, and Growth curve } \\
\text { analysis. }\end{array}$ \\
\hline $\begin{array}{l}\text { BSC and } \\
\text { Employee Well- } \\
\text { being }\end{array}$ & $\begin{array}{l}\text { Significant } \\
\text { (positive) }\end{array}$ & 2018 & LEMMA, A & $\begin{array}{l}\text { An assessment on the } \\
\text { implementation of BSC } \\
\text { concerning employee } \\
\text { performance: The case of } \\
\text { Oromia Regional Health } \\
\text { Bureau }\end{array}$ & $\begin{array}{l}\text { The study involved } 214 \\
\text { employees working at the ORHB }\end{array}$ & $\begin{array}{l}\text { SPSS (Statistical Package for } \\
\text { Social Sciences) version } 25\end{array}$ \\
\hline
\end{tabular}




\begin{tabular}{|c|c|c|c|c|c|c|c|}
\hline $\begin{array}{l}\text { BSC } \\
\text { Employee } \\
\text { being }\end{array}$ & $\begin{array}{r}\text { and } \\
\text { Well- }\end{array}$ & $\begin{array}{l}\text { Significant } \\
\text { (positive) }\end{array}$ & 2010 & OPIYO, R.M. & $\begin{array}{l}\text { Influence of BSC on } \\
\text { Employee Job Satisfaction: A } \\
\text { survey of Cooperative Bank } \\
\text { of Kenya Ltd }\end{array}$ & $\begin{array}{l}\text { The population consists of } \\
\text { 1.947(Co-operative Bank Human } \\
\text { Resources Division. January } 2008\end{array}$ & $\begin{array}{l}\text { Confirmatory Factor Analysis } \\
\text { (CFA) }\end{array}$ \\
\hline $\begin{array}{l}\text { BSC } \\
\text { Employee } \\
\text { being }\end{array}$ & $\begin{array}{r}\text { and } \\
\text { Well- }\end{array}$ & $\begin{array}{l}\text { Significant } \\
\text { (positive) }\end{array}$ & 2017 & $\begin{array}{l}\text { Narayanamma, } \\
\text { P. Lakshmi }\end{array}$ & $\begin{array}{l}\text { A study on Impact of BSC } \\
\text { implementation in Job } \\
\text { Satisfaction of Employees in } \\
\text { Selected Public and Private } \\
\text { Sector }\end{array}$ & $\begin{array}{l}\text { Questionnaires were distributed to } \\
250 \text { respondents in selected public } \\
\text { (125) and private (125) sectors. }\end{array}$ & $\begin{array}{l}\text { The data is analyzed using } \\
\text { various statistical tools such as } \\
\text { mean, standard deviation, and } \\
\text { regression. }\end{array}$ \\
\hline
\end{tabular}

\section{Copyrights}

Copyright for this article is retained by the author(s), with first publication rights granted to the journal.

This is an open-access article distributed under the terms and conditions of the Creative Commons Attribution license (http://creativecommons.org/licenses/by/4.0/). 